\title{
Sciendo
}

Transport and Telecommunication, 2020, volume 21, no. 1, 1-14

Transport and Telecommunication Institute, Lomonosova 1, Riga, LV-1019, Latvia

DOI 10.2478/ttj-2020-0001

\section{BEHAVIOR OF AIR PASSENGER DEMAND IN A LIBERALIZED MARKET}

\author{
Diana Tascón Hoyos ${ }^{1}$, Oscar Díaz Olariaga ${ }^{2}$ \\ ${ }^{1}$ Facultad de Ciencias y Tecnologías, Universidad Santo Tomás \\ Carrera 10 \#72-50, Bogotá, Colombia \\ dianatascon@ustadistancia.edu.co \\ ${ }^{2}$ Facultad de Ingeniería Civil, Universidad Santo Tomás \\ Carrera 9 \#51-11, Bogotá, Colombia \\ OscarDiazOlariaga@usantotomas.edu.co
}

This article analyzes the behavior of the demand of domestic and international air passengers in a context of liberalized air transport market and with a total deregulation of airfares (using as case study the Colombian air transport market), and where it is also contemplated the influence, on this demand, of several factors of diverse origin (economic, market / competition and geographic). And due to the complexity of the air transport system, the use of System Dynamics is considered appropriate as an analysis tool. The main results indicate a convergence (in the study period) to a stabilization status of the load factor, which suggests that the air operators were able to better understand the behavior of the demand and thereby better adjust their supply.

Keywords: air passenger demand; airport; air transport; system dynamics; liberalization; Colombia

\section{Introduction}

In airports the term "capacity" is related with the performance of a given infrastructure or facility. In this context, the capacity of an airport is calculated and analyzed by studying the behavior of certain entities. These entities can be: operations of aircraft (landings and take-offs), air passengers (especially demand), or movements (incoming / outgoing) of air cargo (Kazda and Caves, 2015; Janic, 2009). One of the most important objectives of an adequate demand management is to help maintain efficient operations at airports threatened by congestion or already congested to intern avoid, or at least mitigate, the serious problem of delays (de Neufville and Odoni, 2013; Horonjeff et al., 2010). Therefore, and based on these concepts, a deep understanding of the behavior of the demand (of air passengers) is a fundamental part of the development plan of an airport, which should lead to the optimal use of the installed capacity, what will be a vital input to assess and forecast the volume and type of air passenger demand in the future. This information (current and / or planned for the future) will help decision making by airport planners (in short, medium and long term) regarding the development and investment of new facilities and infrastructure (runways, aprons, passenger terminal building, support facilities, etc.) (Suryani et al., 2010). Mention and highlight that in countries whose air markets are liberalized (or have been recently), there is a significant development and growth of demand which must be analyzed, since with the knowledge of the behavior of demand airport planners can better manage their developments and investments in the national airport system.

Colombian air transport is experiencing a staggering and dynamic development that began approximately two decades ago. This period coincides with the beginning of a continuous implementation of public policies prepared specifically for the air transport sector with the aim of promoting and encouraging it. The growth of air traffic in Colombia has been reinforced since the 1990s by a public policy of liberalization of airspace in the domestic and foreign markets, and by redirecting public and private investment towards the modernization and updating of airport infrastructures, giving in concession the busiest airports in the country (Díaz Olariaga and Ávila, 2015). The first generation of airport concessions was implemented in the mid-1990s, and from that moment three more generations have been developed (Díaz Olariaga, 2017). As a result of public policies, both privatization and public investment in airport infrastructure (accompanied by deregulation policies of the aviation sector), in the last two and a half decades passenger transport (total) grew by $863 \%$ (Aerocivil, 2019). 
This research proposes a System Dynamics (SD) model to study and understand the behavior of air seats demand, for which we focus on the simulation and analysis of the load factor, since this measure represents the efficiency with which the airlines adjust their offer to the market demand conditions. Thus, it is analyzed how with the passage of time and after the liberalization of the market this performance measure has behaved. It is remarkable that this is directly influenced by several factors of different origin (economic, market, geographic). Due to the complexity of the air transport system, the use of System Dynamics is considered appropriate as an analysis approach (Angarita-Zapata et al., 2016; Suryani et al., 2010; Shepherd and Emberger, 2010; Miller and Clarke 2007; Lyneis, 2000). The Systems Dynamics approach is based on the theory of feedback control and is developed with mathematical simulation models that use linear and nonlinear differential equations (Bala et al., 2016; Ogata, 2014; Hovmand, 2013; Fabien, 2008; Sterman, 2000; Phelan, 1999; Coyle, 1996).

The simulation takes data from the case study adopted for this research, which is the air transport system in Colombia, from which 58 airports were chosen, open to commercial traffic (most of the network). The airport network in Colombia is distributed throughout the country, this large geographic coverage of the Colombian airport system has encouraged the movement of air passengers in a relevant way, especially in the last two decades, providing a mobility solution due to two determining situations: first, the country's complex geography (crossed from southwest to northeast by three mountain ranges of the Andes), and second, to the deficiency (in coverage, capacity and technology) of existing land and railway communication systems (Diaz Olariaga and Carvajal, 2016).

Therefore, this research contemplates the behavior of the demand of domestic and international passengers in the origin-destination criterion, where the origin node is the Bogotá-El Dorado International Airport (BOG) in the capital of Colombia and the destinations are, for domestic passengers: the points of the nodes in the network that connect the origin (BOG) in what is called "main domestic routes", and for international passengers: the main international destinations (which connect with BOG), which are called "main international routes". In both cases, these routes concentrate most of the air traffic demand (Diaz Olariaga and Carvajal, 2016). It is worth mentioning that the air transport industry in Colombia has been liberalized since 1991, and the airfare market has been totally deregulated since mid-2012 (Díaz Olariaga and Zea, 2018).

\section{Literature review}

There are many studies that address the various aspects of the liberalization of the air transport market (or industry). These studies deal with issues such as the spatial effects of deregulation on connectivity and accessibility (Díaz Olariaga and Carvajal, 2016; O'Connor, 2003; Bowen, 2002, 2000), market competition and consolidation (Goetz, 2002; Goetz and Sutton, 1998; Debbage, 1993), network structures (Díaz Olariaga and Zea, 2018; O'Kelly, 1998; Shaw and Ivy, 1994), airfare prices (Vowles, 2006; Stavins, 2001; Oum et al., 1996), and airline alliances (Fan et al, 2001; Oum et al., 2001; Vowles, 2000). Other studies focus on the analysis of diverse situations (e.g. demand behavior), in the post liberalization context, particularized in certain countries or regions; in addition to the countless jobs in relation to the United States, we have, for example, from Europe (Eriksson and Pettersson, 2012; Fan, 2006; Goetz and Graham, 2004), from Canada (Oum, 1991), from Australia (Hooper, 1998; Forsyth, 1991), from Asia (Bowen, 2000; Bowen and Leinbach, 1995), from Brazil (Oliveira et al., 2016; Koo and Lohmann, 2013), from Central and Eastern Europe (Jankiewicz and Huderek-Glapska, 2015), from Africa (Njoya et al., 2018; Abate, 2016; Dobruszkes et al., 2016; Njoya, 2015; Surovitskikh and Lubbe, 2015), and finally from Colombia, where there is only one related research, that of Díaz Olariaga et al., (2017). From the point of view of public policy, Koo and Lohmann (2013) examine the relationship between the volatility of aeronautical public policy and the spatial evolution of the air transport supply; these authors focus on the domestic aviation sector of two comparative cases, Australia and Brazil. On the other hand, Rolim et al. (2016) analyze the development of the demand in recently privatized airports, applied to the case of Brazil. Changes in traffic concentration at airports as a result of liberalization have also been analyzed (Díaz Olariaga and Zea, 2018; Rodrigues et al., 2015; Koo et al., 2013; Halpern, 2011; SuauSánchez and Burghouwt, 2011; Derudder and Witlox, 2009).

Thus, the forecast of the air passenger demand and its historical evolution (since the liberalization of the aviation industry around the world), has been studied extensively (and with a great diversity of models and methodologies), and for this there is a rich related scientific literature. But the same does not occur with the study of demand behavior when factors such as capacity, network structure, economy, market and geography are considered simultaneously. Looking in the literature, in what refers to the behavior of air passenger demand, we find: Koo et al. (2013) analyze the relationship between tourism 
demand and air transport capacity; Marazzo et al. (2010) investigate the relationship between the demand for air transport and economic growth; Lewe et al. (2014) argue that the complexity of the transportation system requires a holistic solution approach that employs multiple modeling paradigms, such as agentbased modeling and System Dynamics; and Minato and Morimoto (2011) use simulation dynamics models to propose optimal strategies to maintain the flow of passenger traffic at domestic level in Japan, where most Japanese regional airports are commercially unstable because the demand for air travel is low and fluctuating.

On the other hand, not many academics have used System Dynamics to research the management of air transport. Lyneis (2000) used SD models to forecast aircraft demand. Miller and Clarke (2007) used SD models to evaluate investment strategies in aviation infrastructure. Suryani et al. (2010) established an SD model to simulate the expansion of passenger terminal capacity and forecast passenger demand.

\section{Application case: Colombia}

\subsection{Liberalization in the airport sector}

On airport infrastructure management, Colombia has followed the general trend in Latin America to give in concession the administration of these infrastructures (Díaz Olariaga, 2017).

Consequently, since the mid-nineties, and in several phases, called generations, the Colombian government gave in concession the operation (never ownership) of several airports in the country (19 to date), among which are included the largest and most important that the public sector manages, in order to obtain better administration, modernization and expansion, operation, commercial exploitation and maintenance of the most used air terminals (Díaz Olariaga, 2017). Under the stated objective of the airport concessions of the country, the company, business, consortium or concessionaire of airport acts solely as administrator / operator thereof. As a result of public policies, both privatization and public investment in airport infrastructure, and together with deregulation policies of the commercial airline sector, where airfares have been fully liberalized since 2012, in the last two and a half decades passenger transport (total) grew by $863 \%$ (Aerocivil, 2019).

In other matters, it can be stated that air transport in Colombia practically has no competition (at domestic level) with other means of transport, especially for medium and long distances, due to two decisive situations: first, the country's complex geography (crossed from southwest to northeast by three mountain ranges of the Andes Mountain Range), and second, to the deficiency (in coverage, capacity and technology) of existing land (non-existence of medium or high capacity highways) and railway (nonexistence of a passenger train system / network) communication systems (Diaz Olariaga and Carvajal, 2016). And finally, and due to the geographical distribution of the airports in the country, there is practically no intra-airport competition.

\subsection{Liberalization in the airline sector}

With regards to the liberalization of airfares in Colombia, from 1992 until the development of Resolution 3299 of 2007 of the Public Aeronautical Authority (hereinafter Aerocivil) (on domestic and international fares of regular air passenger transport), Aerocivil's involvement in aeronautical fares consisted in the approval of the fares proposed by the airlines for a certain route and not in the direct imposition thereof. The proposed fares and its conditions had to comply with the technical criteria of equity and sufficiency established by the Colombian Aeronautical Regulations (public document that regulates all aeronautical / civil aviation activity in Colombia). Resolution 3299 of 2007 modifies the fare regime by eliminating the minimum fares for domestic and international air transport companies. Said resolution stipulates that companies may freely set fares, provided that said fares do not exceed those that Aerocivil has approved for other airlines at the maximum level. The immediate effect of this (partial) fare liberalization was the substantial reduction in the fares set by companies for both domestic and international destinations. Finally, in 2012 there was a total deregulation of airfares, a policy that has been maintained to date.

In other matters, in Colombia, the entry of private air transport operators into the market with a FSC (Full-Service Carrier) business model occurred very soon after the liberalization of the sector (beginning of the 1990s). But the entry into the market of low-cost airlines (LCC), was many years after the liberalization. The only three LCCs that started their activities in the Colombian market, and still operating today, are EasyFly (born in 2006 and started operations in 2007), VivaColombia (born in 2009 but starts operations in 2012), and Wingo (which started operations in 2016). Finally, to mention that the 
airline Avianca, the oldest in Colombia (former Colombian flag company, now a private company), dominates the market for both domestic and international destinations (Díaz Olariaga and Ávila, 2015).

With regards to the international market, since 2009 in Colombia a policy of total deregulation has been consolidated, through the promotion of signing agreements of greater freedoms up to the so-called open skies with the countries with which there are air transport relations to guarantee a completely free market, with the purpose of moving towards free market access and fares.

\section{Methodology}

\subsection{Conceptual analysis}

The demand for flights / air tickets is determined by several factors, economic, geographic and market conditions (Srinidhi, 2010). This study seeks to incorporate, in a System Dynamics model, variables related to these origins with the purpose of having a model that allows identifying interrelations between such variables, with special emphasis on their impact on the behavior of demand and consequently the load factor.

System Dynamics is an approach that incorporates a set of tools that favor the understanding of complex environments, it uses tools such as causality diagrams, promotes the systemic thinking of those responsible for the processes, also represents the dynamic complexity of the system of interest and offers the advantage of simulating the model so that the consequences of the interactions between the variables can be evaluated. The long-term collateral effects of decision-making policies can be anticipated before they are executed in the system (Sterman, 2000).

The use of systems dynamics in the modeling and simulation of complex systems involves the development of a series of activities, which are synthesized and related to the object of study in Table 1.

Table 1. Activities, methods and products obtained

\begin{tabular}{lll}
\hline Activities & Methods & Products \\
\hline $\begin{array}{l}\text { Definition and structuring of the dynamic } \\
\text { behavior of the system }\end{array}$ & $\begin{array}{l}\text { Define and diagram the following elements by } \\
\text { mapping the system: } \\
\text { Limits of the model } \\
\text { Subsystems } \\
\text { Structures of causality }\end{array}$ & $\begin{array}{l}\text { Conceptual mapping of the } \\
\text { model }\end{array}$ \\
Flows and levels & $\begin{array}{l}\text { Quantification involves: } \\
\text { Definition of decision rules to govern the system } \\
\text { Estimation of parameters, interrelations and initial } \\
\text { conditions } \\
\text { Consistency testing }\end{array}$ & $\begin{array}{l}\text { Quantification of the } \\
\text { model }\end{array}$ \\
Simulation of scenarios & $\begin{array}{l}\text { Carry out the simulation and analyze the behavior of } \\
\text { the stipulated response variables }\end{array}$ & $\begin{array}{l}\text { Results and analysis of the } \\
\text { simulation }\end{array}$ \\
\hline
\end{tabular}

\subsection{Conceptual mapping of the model}

The limits of the model are given by its scope, for the study case the most relevant destinations / routes are considered both domestic and international, and the behavior of the passenger load factor for flights originating from a single origin and headed to multiple destinations within an airport network. The model takes as its limits the generation of supply, measured in seats offered by air transport operators, and the demand, measured by seats actually occupied. These variables are aggregated for all the destinations included in the model, their unit of measurement is number of seats per month and domestic and international routes are studied separately.

Within the subsystems that make up the model, we have the network of domestic and international airports (selected), from which the nodes with the highest passenger traffic were taken, the offer / demand ratio, the load factor (relationship between offer and actual demand), also the relations between offer and demand with economic variables, such as the Market Representative Exchange Rate (TRM) and the Consumer Price Index (CPI).

Feedback loops can occur in a reinforcing or balancing type. Reinforcing loops represent increasing or decreasing actions in systems, while balancing is a self-correcting mechanism that counteracts and opposes change (Sterman, 2000; Maani and Cavana, 2007; Setianto et al., 2014). For the 
proposed subsystems, the causality structures identified are those shown next. First, the expected relationships between some variables are presented: offer (measured as number of seats offered), demand (measured as number of seats demanded), and number of airlines per route. This behavior reflects two reinforcing feedback cycles, in which the offer encourages demand, this in turn the number of supplying airlines, and therefore the number of seats offered (see Figure 1).

Then, over this loops two economic variables that would influence the above described behavior are incorporated, those are: the Exchange Rate (Market Representative) and the Consumer Price Index (CPI), obtaining what is represented in Figure 2. As well as the expected impact (increase or decrease) that an increase in the variable in the tail of the arrow would have on the one that is in the tip; for instance, an increase in CPI is expected to generate a decrease in demand.

Since the behavior of these variables changes in relation to time (Handou et al., 2009), the year of operation is included in the model, proposing the relationships shown in Figure 3.

Finally, the load factor variable is introduced, which is considered for the purposes of this study as one of the most relevant response variables. The relationships are shown in Figure 4.

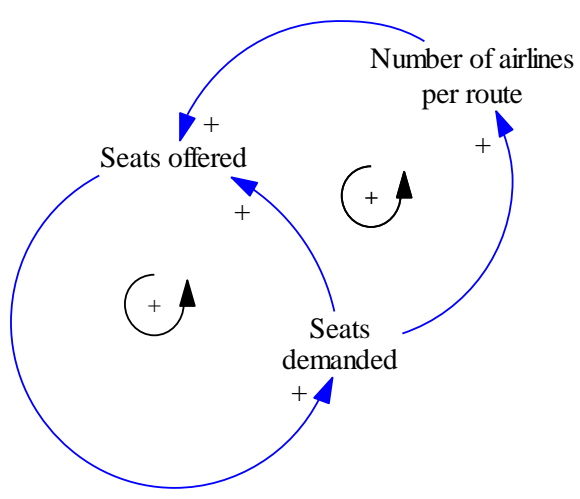

Figure 1. Model initial loops diagram

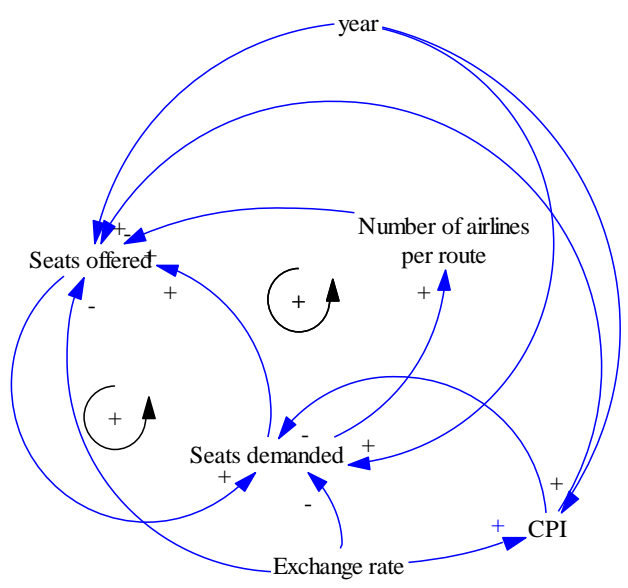

Figure 3. Model loops diagram adding year of operation

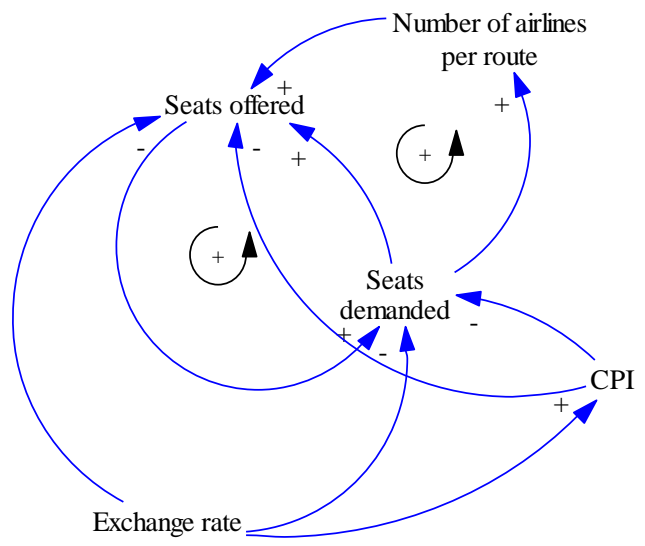

Figure 2. Model loops diagram adding economic variables

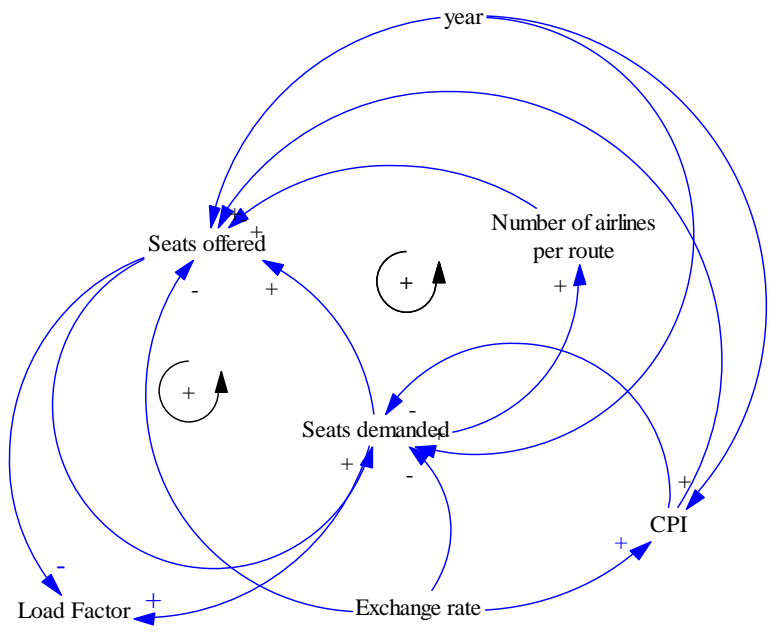

Figure 4. Model loops diagram including load factor

\subsection{Model quantification}

The air traffic data used in the construction of the equations that make up the model take place between 2013 and 2017 and correspond to the main domestic and international destinations from the Bogotá-El Dorado International Airport, in the capital of Colombia (Aerocivil, 2019); they are shown in Tables 2 and 3. Maps 1 and 2 illustrate the geographical location of all airports-destinations under study. 
Table 2. Domestic destinations included in the quantification of the model, and with a single origin (BOG) (in parenthesis the IATA airport code)

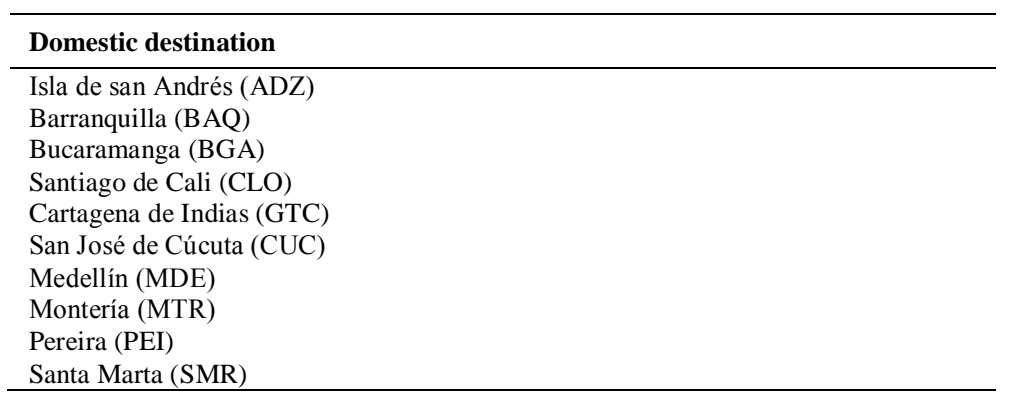

Table 3. International destinations included in the quantification of the model, and with a single origin (BOG) (in parenthesis the IATA airport code)

\section{International destination}

Buenos Aires, Argentina (BUE)

Cancún, Mexico (CUN)

Ciudad de México, Mexico (MEX)

Ciudad de Panamá, Panama (PTY)

Fort Lauderdale, USA (FLL)

Lima, Peru (LIM)

Madrid, Spain (MAD)

Miami, USA (MIA)

New York, USA (JFK)

Quito, Ecuador (UIO)

Santiago de chile, Chile (SCL)

Sao Paulo, Brazil (GRU)

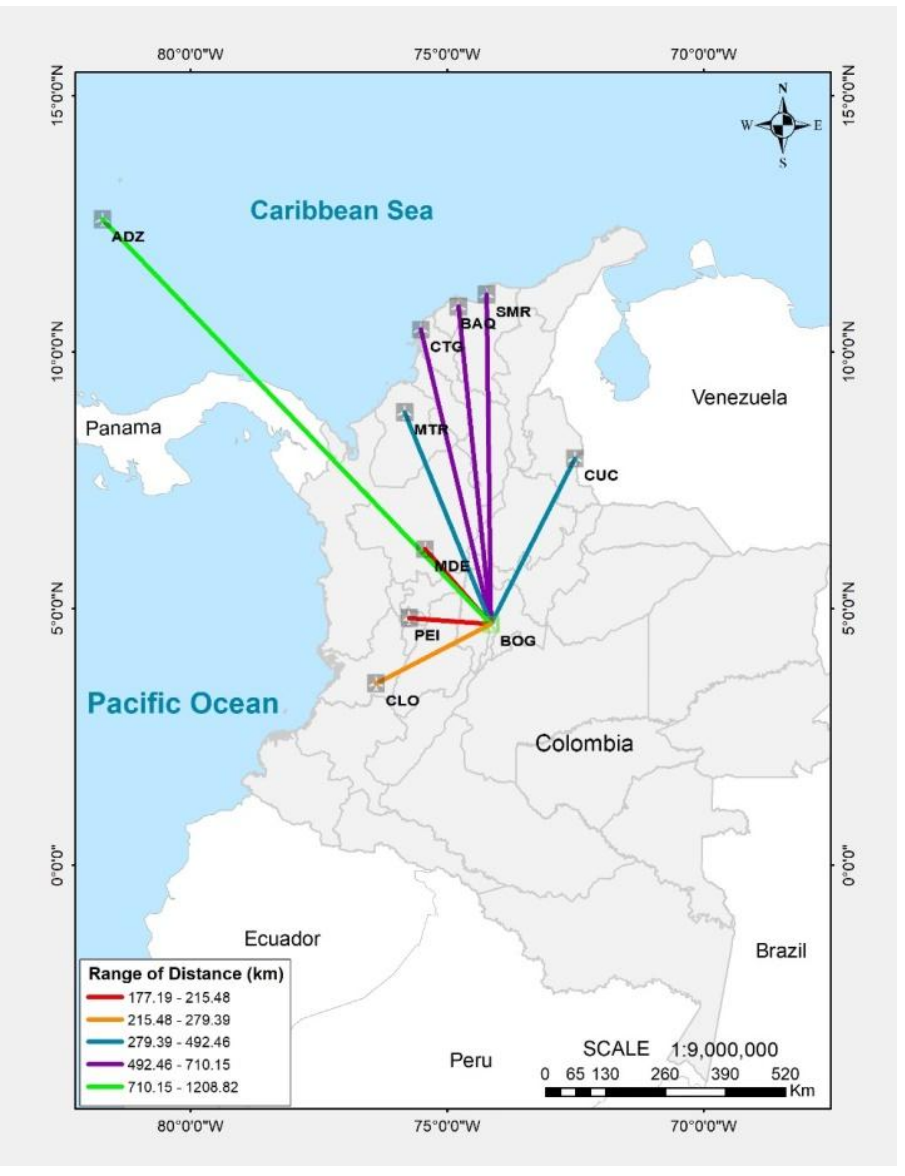

Map 1. Main domestic routes under study 


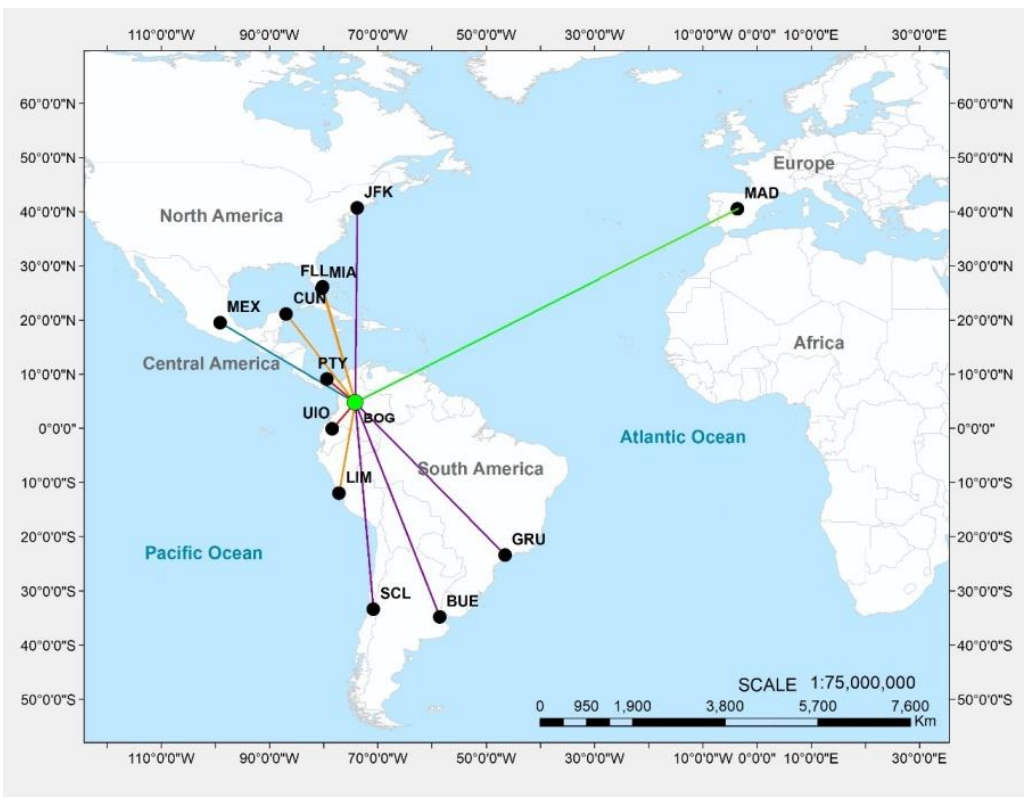

Map 2. Main international routes under study

Now, the general equation and particular observations on its formulation for some of the model variables are presented. The functional relationships are shown omitting details of structures and parameters of each equation. It is highlighted that the equations were generated independently for domestic and international destinations.

\section{Calculation of monthly seasonality index for the variation in demand}

The monthly seasonality index for the variation in demand was determined considering the variation in average demand from year-to-year for each month, and a conventional monthly seasonality calculation was performed. There was obtained a seasonal index for each month; in both cases (domestic and international flights), the maximum values were observed during December and July, while the minimum were in February, it goes from 0.87 to 1.05 for domestic flights, and from 0.85 to 1.14 for the internationals.

\section{Formulation of the expected increase in demand}

The linear regression function was used to formulate the behavior of the increase in the demand for air tickets year-to-year and the monthly seasonality index indicated in the previous paragraph was included in its formulation. Conditional relationships were included with the number of seats demanded and the number of seats offered during the period, so the functional relationship follows what is summarized in the equation (1).

Increase in demand $=f$ (year of operation, month, seats demanded, seats offered).

Here we use a conditional formula that contains 12 parts for introducing the effect of the seasonality index, also it is consider the effect of time year by year reflected in the use of year of operation and the relation between demand and offer.

\section{Formulation of the function of the expected decrease in demand}

The approximation to this equation is based on the behavior of the available data regarding the decrease in demand and its relation with supply. This equation includes a factor of decrease in the supply calculated in case the corresponding supply is not enough to cover it. This could be the result of strategies such as the increase in ticket prices as the available seats run out and the date of the operation approaches. It is also expected that the demand will be influenced by the Exchange Rate, since it affects the price of the ticket. However, for the data available, no logical function was found to reflect this behavior, so 
although, due to its expected relevance, the variable Exchange Rate is preserved in the model, it is not having an impact on the behavior of the system. The functional relationship obeys to what is synthesized in equation (2).

Decrease in demand $=f($ Exchange rate, seats offered, seats demanded $)$

\section{Formulation of the function of the expected increase in offer}

For this case, a direct relationship was considered with the trend in the demand resulting from the second of the calculations mentioned in this section, using a delay function which reveals that the number of seats offered for a particular month is related to both the behavior of the current year and to the demand of the same month in previous years. On the other hand, the number of airlines offering was included in a conceptual manner, although for this case this factor did not have relevance, since it remained constant during the period studied. Thus, the function depends on the values taken by the variables indicated in the equation (3).

Increase in of fer $=$

$f(y e a r$ of operation, increase in demand, delay, number of airlines per route)

\section{Formulation of the function of the expected decrease in offer}

It was related to an adjustment based on the load factor that in turn follows the relationship between what is offered and what is demanded. The general functional relationship is shown in the equation (4).

Decrease in offer $=f($ Load factor, seats offered $)$

In order to clarify the impact of this function on the model, let's take the specific structure for the international flights case, which is: $f=$ (If Then Else(Load Factor < 0.8, 1.5 * (1 - Load Factor) * Seats offered, 0 )). This basically means that when the load factor is not higher than $80 \%$, the model will show a tendency to decrease the offer. In this sense, it is important to state that the dynamic structures involved make this relationship nonlinear and that the offer behavior in a given period is also determined by other modeled aspects.

\section{Formulation of the cumulative supply variable for the simulated period}

It is a level variable, so its formulation obeys to what is presented in the equation (5).

Seats offered $=\int($ Increase in the supply - Decrease in the supply $) d t$

\section{Formulation of the cumulative demand variable for the simulated period}

It is a level variable, so its formulation obeys to what is presented in the equation (6).

Seats demanded $=\int($ Increase in the demand - Decrease in the demand $) d t$

\section{Formulation of the load factor variable} equation (7).

The formulation obeys the calculation of a fractional level of occupation, as presented in the

Load factor $=($ Seats demanded $/$ Seats offered $)$

The remaining parameters and auxiliary variables that also consist of a formulation and excluded from this section are due to simple and operational calculations required for the correct operation of the simulation.

Figure 5 shows the stock and flow diagram resulting from the conceptualization and quantification presented. 


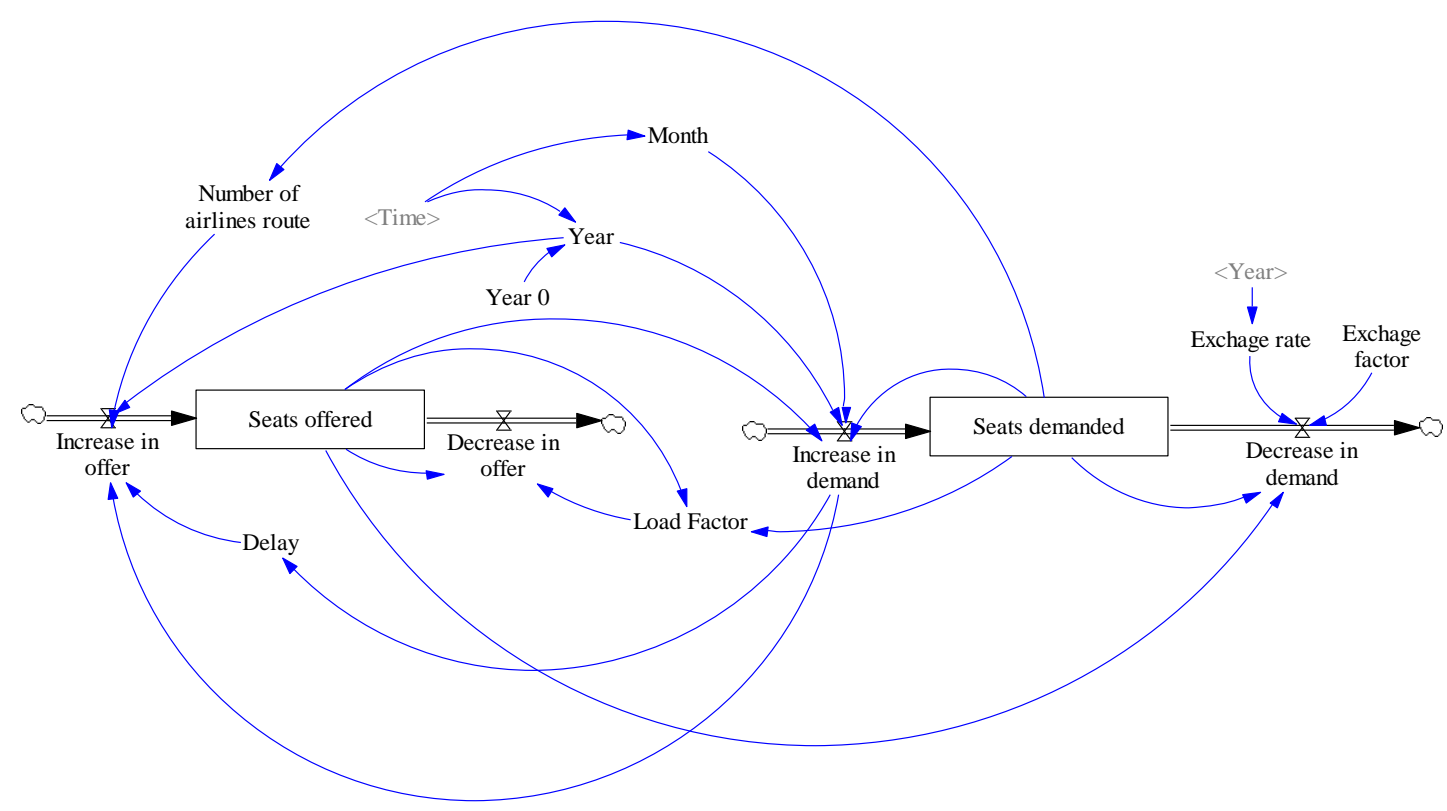

Figure 5. Stock and flow diagram

\section{Results}

Understanding the load factor as a response measure of the system and that which measures the efficiency of the relationship between what is offered and what is demanded, its behavior in the modeling carried out is illustrated in Figures 6 and 7. On the horizontal axis we have the month (data of 60 months between January 2013 and December 2017 were taken). It was observed that in all cases the demand was exceeded by the offer and the load factor for domestic routes remained between $80 \%$ and $98 \%$ and between $80 \%$ and $90 \%$ for international routes.

In order to validate the ability of the model to represent the behavior of this performance measure, the simulation results were contrasted with those available for the real system. MAPE (Mean Absolute Percentage Error), was calculated, the results are shown in Table 4.

Table 4. MAPE (Mean Absolute Percentage Error) for Load Factor

\begin{tabular}{ll}
\hline Load factor & MAPE \\
\hline Domestic flights & $14.26 \%$ \\
International flights & $5.44 \%$ \\
\hline
\end{tabular}

It should be noted that one of the possible causes for the model to have a greater MAPE for the load factor of domestic flights, is attributable to the fact that in 2017 there was an abrupt fall in demand, mainly domestic, due to the strike of pilots of the country's main airline (Avianca) that lasted 51 consecutive days and (and where about 10,000 flights were canceled), (Díaz Olariaga, 2019), which means a greatest variability in the process as well as greater deviations when comparing the simulated results with the real data.

The type of behavior reflected in Figures 6 corresponds to a particular form of growth, which for the case study involved a growing correspondence between what is offered and what is demanded and a stabilization in this relationship.

The above shows the convergence that has been generated in the course of time, between offer and demand. It should be noted that for the analyzed period, it is observed that the load factor for domestic flights presented a greater range in its behavior (with respect to the international operation), and stabilized more rapidly, while the range for international flights is smaller (between $80 \%$ and $90 \%$ as previously mentioned), and its convergence has been presented at a more constant increasing rate (see Figure 7).

The interpretation of the previous analysis on the load factor must also consider that during the period of study, both demand and offer have had a constant growth, which is reflected in Figures 8 to 11, that contain the increases in these variables. Finally, to highlight this, Figure 12 shows the average values of the monthly demand for seats on international routes during the period between 2013 and 2017; the data used for this figure comes directly from statistical information of the Public Aeronautical Authority. 


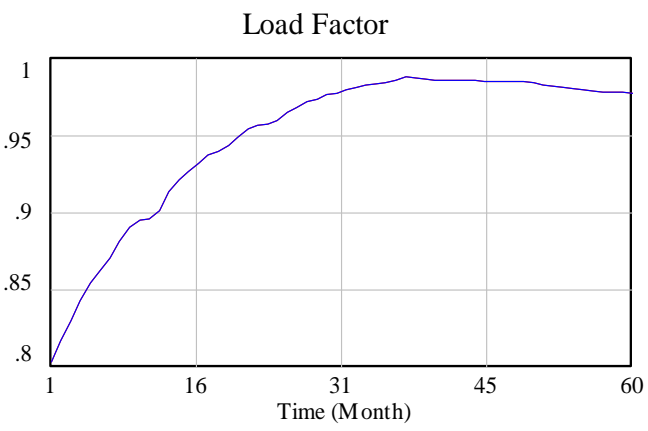

Figure 6. Behavior of load factor - national routes

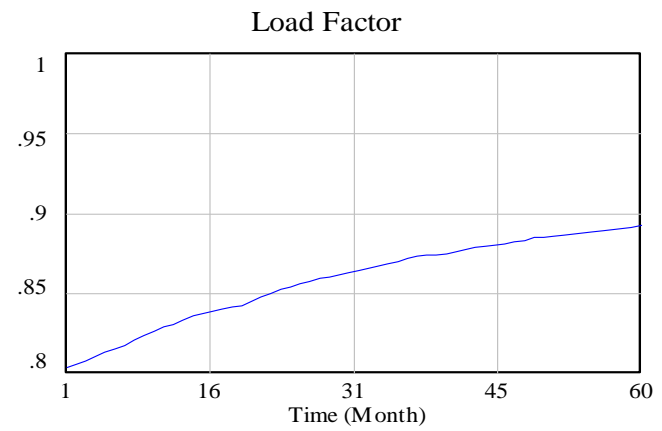

Figure 7. Behavior of load factor - international routes

Figures 8 and 9 show the behavior in the increase in offer over time for the period studied, for domestic and international routes respectively. In the horizontal axis is the corresponding period taking as initial moment January 2013 and end December 2017. These five years are segmented by month and are represented from period 1 to 60 ; in the vertical axis the variable that is being measured is the increase in the offer measured in seats/month. In accordance with the real data of the case, a decrease in the growth rate of the offer is shown over time; also the seasonal behavior of the variable is reflected.

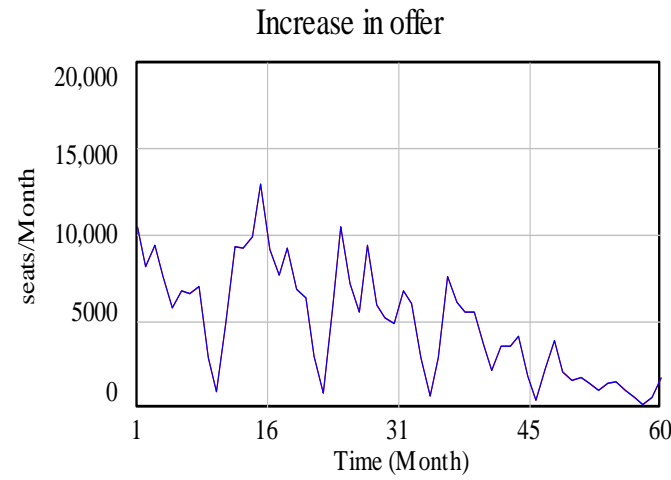

Figure 8. Increase in offer - domestic routes (seats/month)

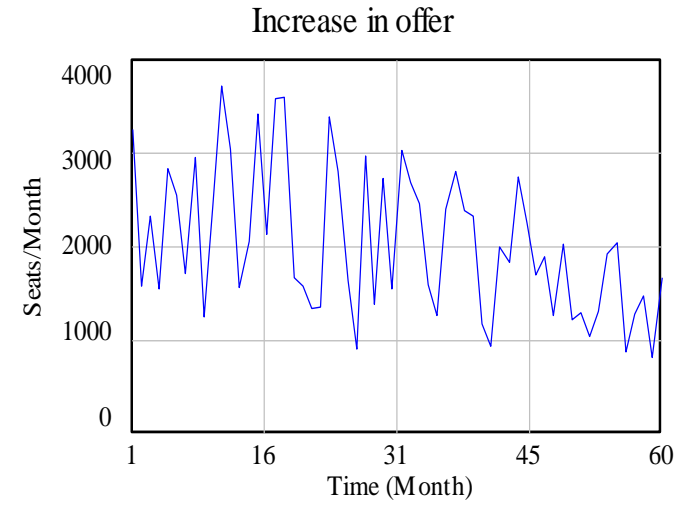

Figure 9. Increase in offer - international routes

Figures 10 and 11 show the behavior of the variable increase in demand, the existing data reflects that in all cases the offer is sufficient to cover the demand, so the evidence available did not giving rise to decreases in demand caused insufficient offer. The increase in demand shows a decreasing behavior and consequently with the data used in its formulation the seasonality detected is reflected according to the month of the year in which the operation of the utilized data occurs.

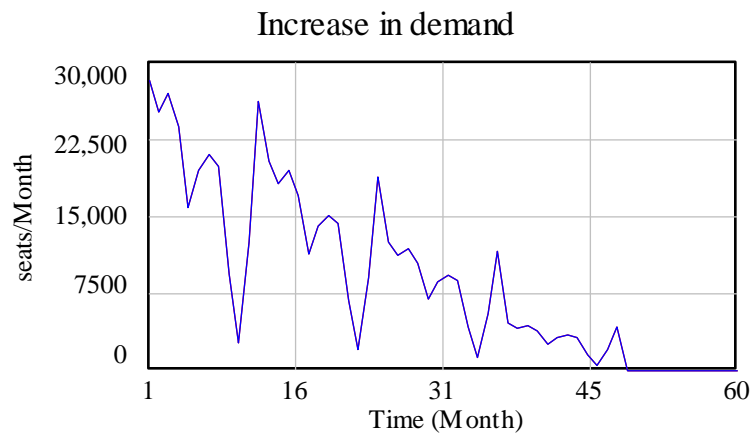

Figure 10. Increase in demand - domestic routes

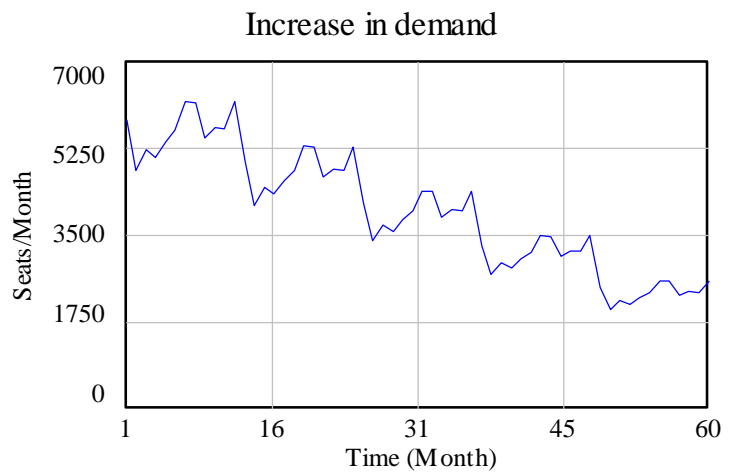

Figure 11. Increase in demand - international routes 


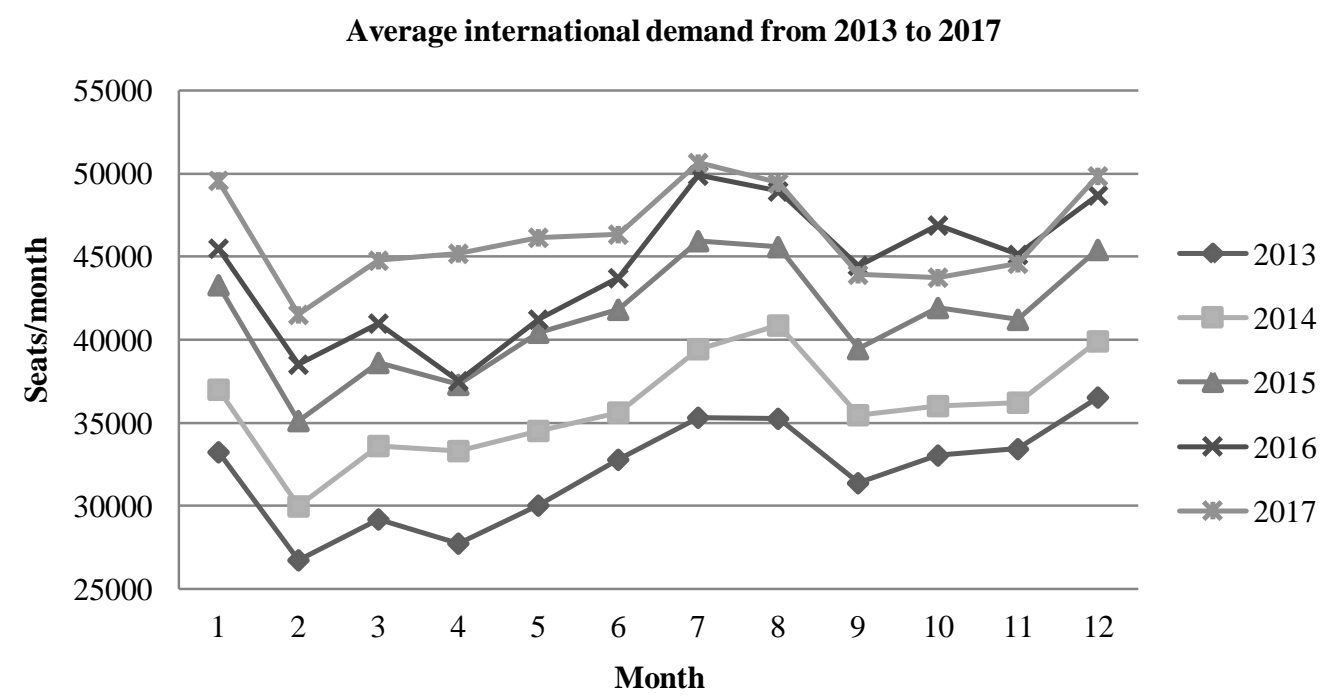

Figure 12. Average international demand from 2013 to 2017

It is to be considered that the variable fare (of the air ticket) was not included in the model since to date there is no reliable information (the "published" fare data that the airlines inform to the regulator are not precise, also they show high variations as a result of commercial promotions). Regarding the distance variable (between nodes or airports), it was not considered taking into account that for the domestic destinations, due to the existing characteristics in Colombia (geographical and non-existence of efficient alternative mass transport systems), air transport does not have competition for medium and long distances (Díaz Olariaga and Carvajal, 2016); similar situation occurs for international destinations (both continental and intercontinental).

\section{Conclusions}

This research presents an approach to study and analyze the behavior of air passenger demand from the point of view of System Dynamics. The results obtained from the use of this approach can be used as inputs to forecast the demand for air passengers and, on the other hand, to estimate the infrastructure and capabilities of the airport system facilities, both current, as well as in the short, medium and long term. With this, decision-making by airport planners is facilitated, both for specific airports and for the entire national airport system. And the most relevant is an in-depth knowledge of the behavior of the demand by the airport managers when there are congested airports in the national airport system, a situation that generates one of the main problems of air transport, delays. As the behavior of the demand for air passengers is highly complex, it is considered appropriate to use System Dynamics, this based on the consideration that the calibrated models that can be obtained with this methodology may be better than those of other methods or approaches.

So, through the use of an SD model it has been possible to analyze the behavior of air transport demand in a high growth liberalized market. The analysis, on the selected case study, begins after the complete deregulation of airfares and for a period of five years (2013-2017). The main results of the model indicate, first, a high variability in the behavior of the international flights load factor, which suggests that in the international flights market it is not so easy to adjust supply to demand, and in the different times throughout the year. Regarding domestic flights, the load factor has a lower range and has tended to stabilize and converge with the passage of time, which suggests that air transport operators were able to better understand the behavior and evolution of demand at domestic level and thereby better adjust its offer. The model was able to identify the periods of greatest demand and supply (peak periods), namely: end / beginning of year, Easter, austral winter holidays (or mid-year).

Finally, the approach proposed here to know, analyze and evaluate the behavior of air passenger demand could be considered as valid for: a) the acquisition of valuable information for the development of demand forecasts; b) management (current) of the capacity of the airport (or airport system) and especially in the congested airports of the system; c) management of the service levels of the different airports; and d) planning (and investment) of airport infrastructure and facilities. 


\section{References}

1. Aerocivil (2019). Estadísticas. https://goo.gl/pFY3mV

2. Abate, M. A. (2016). Economic effects of air transport market liberalization in Africa. Transportation Research Part A, 92, 326-337.

3. Angarita-Zapata, J. S.; Parra-Valencia, J. A.; Andrade-Sosa, H. H. (2016). Understanding the Structural Complexity of Induced Travel Demand in Decision-Making: A System Dynamics Approach. Organizacija, 49(3), 129-143.

4. Bala, B., Arshad, F.; Noh, K. (2016). System Dynamics: Modelling and Simulation. Singapore: Springer.

5. Bowen, J. (2002). Network change, deregulation, and access in the global airline industry. Economic Geography, 78(4), 425-439.

6. Bowen, J. (2000). Airline hubs in Southeast Asia: national economic development and nodal accessibility. Journal of Transport Geography, 8(1), 25-41.

7. Bowen, J.; Leinbach, T. (1995). The state and liberalization: the airline industry in the East Asian NICs. Annals of the Association of American Geographers, 85(3), 468-493.

8. Coyle, R.G. (1996). System Dynamics Modelling: A Practical Approach. Boca Raton: CRC Press.

9. de Neufville, R.; Odoni, A. (2013). Airport Systems, Planning, Design, and Management. New York: McGrawHill.

10. Debbage, K. (1993). U.S. airport market concentration and deconcentration. Transportation Journal, 47(1), 115-136.

11. Derudder, B.; Witlox, F. (2009). The impact of progressive liberalization on the spatiality of airline networks: a measurement framework based on the assessment of hierarchical differentiation. Journal of Transport Geography, 17, 276-284.

12. Díaz Olariaga, O. (2019). Influencia del transporte aéreo en la conectividad territorial. Caso de Colombia. XIII Congreso Colombiano de Transporte y Tránsito, 26-28 June 2019, Cartagena de Indias (Colombia).

13. Díaz Olariaga, O.; Zea, J.F. (2018). Influence of the liberalization of the air transport industry on configuration of the traffic in the airport network. Transportation Research Procedia, 33, 43-50.

14. Díaz Olariaga, O. (2017). Políticas de privatización de aeropuertos. El caso de Colombia. Documentos y Aportes en Administración Pública y Gestión Estatal, 29, 7-35.

15. Díaz Olariaga, O.; Girón Amaya, E.; Mora-Camino, F. (2017). Pronóstico de la demanda de pasajeros en aeropuertos privatizados. VI Congreso Internacional de la Red Iberoamericana de Investigación en Transporte Aéreo. 10-12 octubre 2017, Santiago de Chile.

16. Díaz Olariaga, O.; Carvajal, A.F. (2016). Efectos de la liberalización en la geografía del transporte aéreo en Colombia. Cuadernos Geográficos, 55(2), 344-364.

17. Díaz Olariaga, O.; Ávila, J. (2015). Evolution of the airport and air transport industry in Colombia and its impact on the economy. Journal of Airline and Airport Management, 5(1), 39-66.

18. Dobruszkes, F.; Mondou, V.; Ghedira, A. (2016). Assessing the impacts of aviation liberalisation on tourism: some methodological considerations derived from the Moroccan and Tunisian cases. Journal of Transport Geography, 50, 115-127.

19. Eriksson, M.; Pettersson, T. (2012). Adapting to liberalization: government procurement of interregional passenger transports in Sweden, 1989-2008. Journal of Transport Geography, 24, 182-188.

20. Fabien, B. (2008). Analytical System Dynamics. New York: Springer.

21. Fan, T. (2006). Improvements in intra-Europe inter-city flight connectivity, 1996-2004. Journal of Transport Geography, 14(4), 273-286.

22. Fan, T.; Vigeant-Langlois, L.; Geissler, C.; Bosler, B.; Wilmaking, J. (2001). Evolution of global airline strategic alliance and consolidation in the twenty-first century. Journal of Air Transport Management, 7(6), 349-360.

23. Forsyth, P. (1991). The regulation and deregulation of Australia's domestic airline industry. In: Button, K. (Ed.), Airline Deregulation: International Experiences. London: David Fulton Publishers, pp. 48-84.

24. Goetz, A.; Graham, B. (2004). Air transport globalization, liberalization and sustainability: post2001 policy dynamics in the United States and Europe. Journal of Transport Geography, 12(4), 265-276.

25. Goetz, A. (2002). Deregulation, competition, and antitrust implications in the US airline industry. Journal of Transport Geography, 10(1), 1-19. 
26. Goetz, A.; Sutton, C. (1998). The geography of deregulation in the U.S. airline industry. Annals of the Association of American Geographers, 87(2), 238-263.

27. Halpern, N. (2011). Measuring seasonal demand for Spanish airports: implications for counterseasonal marketing. Research in Transportation Business \& Management, 1(1), 47-54.

28. Handou, A.; Oumarou, A.; Mancel, C.; Mora-Camino, F. (2009). A two level optimization approach for long-term planning in a large air transportation network. Inverse Problems In Science \& Engineering, 17(2), 275-286.

29. Hooper, P. (1998). Airline competition and deregulation in developed and developing country contexts - Australia and India. Journal of Transport Geography, 6(2), 105-116.

30. Horonjeff, R.; McKelvey, F.; Sproule, W.; Young, S. (2010). Planning and Design of Airports. New York: McGrawHill.

31. Hovmand, P. (2013). Community Based System Dynamics. New York: Springer.

32. Janic, M. (2009). Airport Analysis, Planning and Design: Demand, Capacity and Congestion. New York: Nova Science Publishers.

33. Jankiewicz, J.; Huderek-Glapska, S. (2015). The air transport market in Central and Eastern Europe after a decade of liberalisation-Different paths of growth. Journal of Transport Geography, 50, 4556.

34. Kazda, A.; Caves, R. (2015). Airport design and operations. Bingley: Emerald.

35. Koo, T.; Halpern, N.; Papatheodorou, A.; Graham, A.; Arvanitis, P. (2015). Air transport liberalisation and airport dependency: developing a composite index. Journal of Transport Geography, 50, 83-93.

36. Koo, T.; Lohmann, G. (2013). The spatial effects of domestic aviation deregulation: a comparative study of Australian and Brazilian seat capacity, 1986-2010. Journal of Transport Geography, 29, 52-62.

37. Koo, T.; Tan, S.; Duval, D. (2013). Direct air transport and demand interaction: A vector errorcorrection model approach. Journal of Air Transport Management, 28, 14-19.

38. Lewe, J-H.; Hivin, L.F.; Mavris, D.N. (2014). A multi-paradigm approach to system dynamics modeling of intercity transportation. Transportation Research Part E, 71, 188-202.

39. Lyneis, J. (2000). System dynamics for market forecasting and structural analysis. System Dynamics Review, 16, 3-25.

40. Maani, K.E.; Cavana, R.Y. (2007). System Thinking, System Dynamics; Managing Change and Complexity. Rosedale (New Zealand): Pearson Education.

41. Marazzo, M; Scherre, R.; Fernandes, E. (2010). Air transport demand and economic growth in Brazil: A time series analysis. Transportation Research, 46, 261-269.

42. Miller, B.; Clarke, J. (2007). The hidden value of air transportation infrastructure. Technological Forecasting and Social Change, 74, 18-35.

43. Minato, N.; Morimoto, R. (2011). Designing the commercial sustainability of unprofitable regional airports using system dynamics analysis. Research in Transportation Business \& Management, 1, 80-90.

44. Njoya, E.; Christidis, P.; Nikitas, A. (2018). Understanding the impact of liberalisation in the EUAfrica aviation market. Journal of Transport Geography, 71, 161-171.

45. Njoya, E.T. (2015). Africa's single aviation market: The progress so far. Journal of Transport Geography, 50, 4-11.

46. Ogata, K (2014). System Dynamics. Harlow: Pearson.

47. O'Connor, K. (2003). Global air travel: toward concentration or dispersal? Journal of Transport Geography, 11(2), 83-92.

48. O'Kelly, M. (1998). A geographer's analysis of hub-and-spoke networks. Journal of Transport Geography, 6(3), 171-186.

49. Oliveira, A.V.M.; Lohmann, G.; Costa, T.G. (2016). Network concentration and airport congestion in a post de-regulation context: A case study of Brazil 2000-2010. Journal of Transport Geography, 50, 33-44.

50. Oum, T.; Yu, C.; Zhang, A. (2001). Global airline alliances: international regulatory issues. Journal of Air Transport Management, 7(1), 57-62.

51. Oum, T.; Zhang, A.; Zhang, Y. (1996). Optimal airport pricing in the hub-and-spoke network. Transportation Research Part B, 30(1), 11-18.

52. Oum, T. (1991). Airline deregulation in Canada. In: Button, K. (Ed.), Airline Deregulation: International Experiences. David Fulton Publishers, London, pp. 124-187.

53. Phelan, S.E. (1999). A note on the correspondence between complexity and system theory. Syst. Pract. Action Res., 12, 237-246. 
54. Rodrigues, R.; Estrada, M.; Fernandes, E. (2015). Spatial concentration and connectivity of international passenger traffic at Brazilian airports. Journal of Air Transport Management, 46, 49-55.

55. Rolim, P.S.W.; Bettini, H.F.A.J.; Oliveira, A.V.M. (2016). Estimating the impact of airport privatization on airline demand: A regression-based event study. Journal of Air Transport Management, 54, 31-41.

56. Setianto, N.; Cameron, D.; Gaughan, J. (2014). Identifying Archetypes of an Enhanced System Dynamics Causal Loop Diagram in Pursuit of Strategies to Improve Smallholder Beef Farming in Java, Indonesia. Systems Research \& Behavioral Science, 31(5), 642-654.

57. Shaw, S.L.; Ivy, R. (1994). Airline mergers and their effect on network structure. Journal of Transport Geography, 2(4), 234-246.

58. Shepherd, S.; Emberger, G. (2010). Introduction to the special issue: system dynamics and transportation. System Dynamics Review, 26(3), 193-194.

59. Srinidhi, S. (2010). Demand model for air passenger traffic on international sectors. South Asian Journal of Management, 17(3), 53-70.

60. Stavins, J. (2001). Price determination in the airline market: the effect of market concentration. The Review of Economics and Statistics, 83(1), 200-202.

61. Sterman, J. D. (2000). Business Dynamics, Systems thinking and modelling for a complex word. Boston: McGraw-Hill.

62. Suau-Sanchez, P.; Burghouwt, G. (2011). The geography of the Spanish airport system: spatial concentration and deconcentration patterns in seat capacity distribution, 2001-2008. Journal of Transport Geography, 19(2), 244-254.

63. Surovitskikh, S.; Lubbe, B. (2015). The Air Liberalisation Index as a tool in measuring the impact of South Africa's aviation policy in Africa on air passenger traffic flows. Journal of Air Transport Management, 42, 159-166.

64. Suryani, E.; Chou, S-Y.; Chen, C. (2010). Air passenger demand forecasting and passenger terminal capacity expansion: A system dynamics framework. Expert Systems with Applications, 37, 2324-2339.

65. Vowles, T. (2006). Airfare pricing determinants in hub-to-hub markets. Journal of Transport Geography, 14(1), 15-22.

66. Vowles, T. (2000). The geographic effects of US airline alliances. Journal of Transport Geography, $8(4), 277-285$. 